2. To: (Receiving Organization)

Spent Nuclear Fuel Storage Projects

Duke Engineering \& Services

5. Proj./Prog./Dept./Div.:

SNF / K Basin

\section{Originator Remarks:}

Document attached for approval and release.

11. Receiver Remarks:

11A. Design Baseline Document? [X] Yes [] No
3. From: (Originating Organization)

Mechanisms Engineering, Fluor Daniel Northwest

6. Design Authority/Design Agent/Cog. Engr.:

L. H. Goldmann
4. Related EDT No:

N/A

7. Purchase Order No:

N/A

9. Equip./Component No.:

N/A

10. System/Bldg./Facility: $105 \mathrm{KE} / 105 \mathrm{KW}$

12. Major Assm. Dwg. No.:

N/A

13. Permit/Permit Application No:

N/A

14. Required Response Date:

September 25, 1997

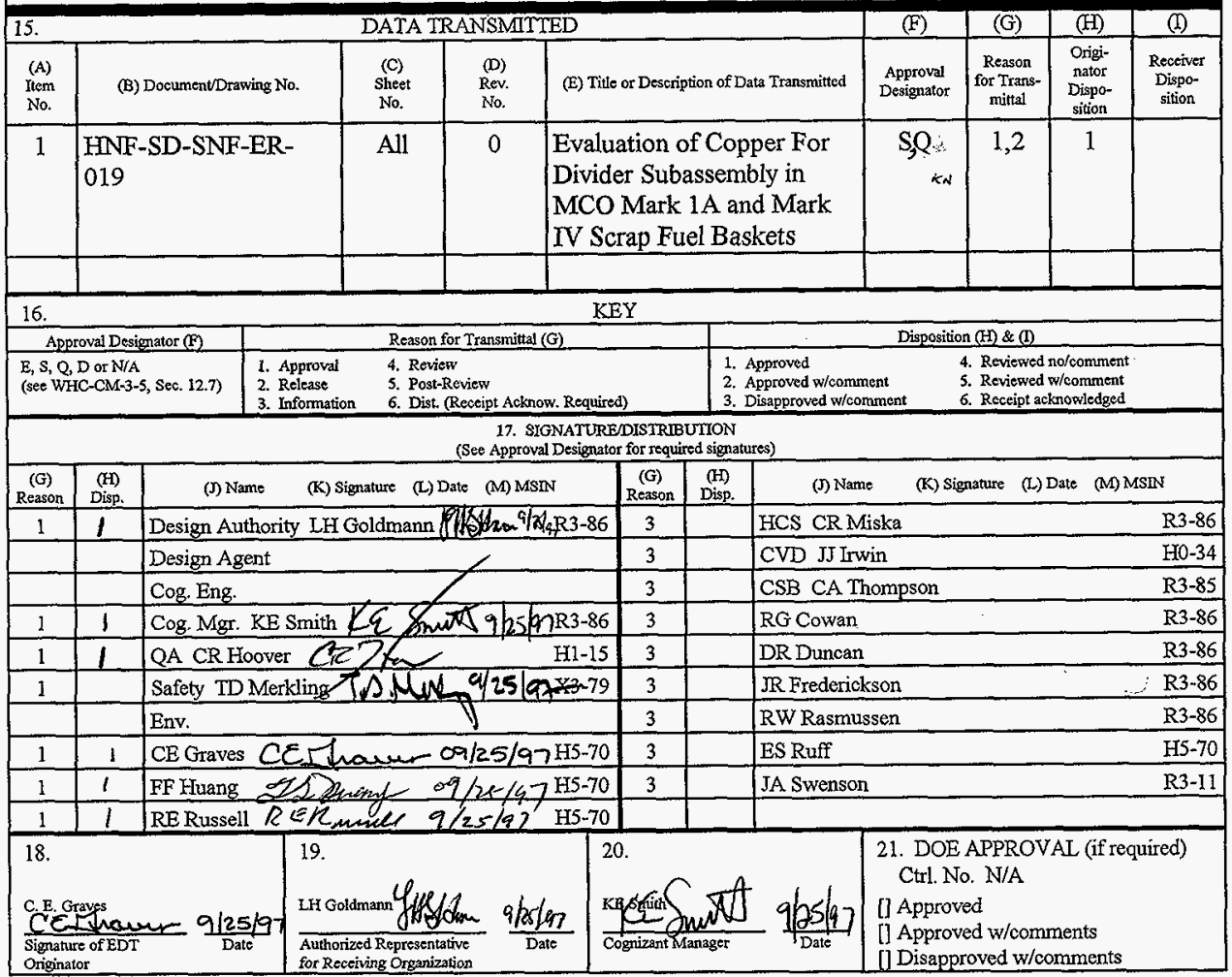




\section{Evaluation of Copper For Divider Subassembly in MCO Mark 1A and Mark IV Scrap Fuel Baskets}

\section{Carolyn E. Graves}

Fluor Daniel Northwest, Richland, WA 99352

U.S. Department of Energy Contract DE-AC06-96RL-13200

EDT/ECN: 604540

Org Code: 481

B\&R Code: EW7040000
UC: 504

Charge Code: LE008

Total Pages: 23

Key Words: MCO

Mark 1A

Mark IV

Spent Nuclear Fuel

Copper

Fuel Basket

Abstract:

This document evaluates the effects of using a copper divider subassembly in the Spent Nuclear Fuel MCO Mark IA and Mark IV scrap fuel baskets. The corrosion, structural, and cost effects are examined.

TRADEMARK DISCLAIMER. Reference herein to any specific commercial product, process, or service by trade name, trademark, manufacturer, or otherwise, does not necessarily constitute or imply its endorsement, recommendation, or favoring by the United States Government or any agency thereof or its contractors or subcontractors.

Printed in the United States of America. To obtain copies of this document, contact: Document Control Services, P.O. Box 1970, Mailstop H6-08, Richland WA 99352, Phone (509) 372-2420; Fax (509) 376-4989

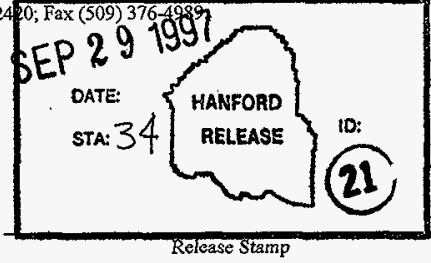


HNF-SD-SNF-ER-019

Revision 0

\title{
EVALUATION OF COPPER FOR DIVIDER SUBASSEMBLY IN MCO MARK 1A AND MARK IV SCRAP FUEL BASKETS
}

\begin{abstract}
The K Basin Spent Nuclear Fuel (SNF) Project Multi-Canister Overpack (MCO) subproject includes the design and fabrication of a canister that will be used to confine, contain, and maintain fuel in a critically safe array to enable its removal from the K Basins. Each $M C O$ consists of a shell, shield plug, fuel baskets (Mark $1 \mathrm{~A}$ or MarkIV), and other incidental equipment. It was proposed to use copper to construct the divider subassembly in the Mark $1 A$ and Mark IV scrap fuel baskets. The use of copper would increase the amount of heat conducted away from the fuel fines area, thus increasing safety margins during Cold Vacuum Drying (CVD).

Three copper alloys were considered for constructing the divider subassembly: C10200 (oxygen-free copper without residual deoxidants), C10800 (oxygen-free low phosphorus copper), and C12200 (phosphorized, high residual phosphorus copper). The room temperature mechanical properties of the coppers depend upon temper and can approximate those of 304L stainless steel at higher-hardness tempers. C10200 and C10800 have the highest electrical and thermal conductivity, while C12200 is about $15 \%$ lower. Elevated temperature yield strength of $C 12200$ is only slightly lower than stainless steel, but the tensile strength is only about one-third that of the stainless steel. The C10200 and C10800 coppers have lower elevated temperature strength levels. The coppers are prone to stress relaxation, but the addition of minute amounts of silver significantly reduce the effects. Thermal expansion coefficients for the coppers are $5.10 \%$ larger than stainless steel. Corrosion resistance of the coppers in the MCO environments are acceptable and approximately equal among the alloys; none are prone to hydrogen embrittlement or stress corrosion cracking.
\end{abstract}

Cost quotes showed C12200 to be about 7\% less than C10200. The C10800 copper is excluded because of its lack of availability. The use of C12200 copper is recommended over the C10200 copper as the Mark $1 A$ and Mark IV scrap basket divider subassembly construction material. 


\section{EVALUATION OF COPPER FOR DIVIDER SUBASSEMBLY IN MCO MARK 1A AND MARK IV SCRAP FUEL BASKETS}

Prepared By:

Reviewed By:

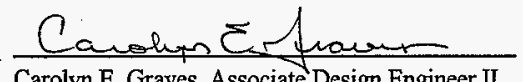

Carolyn E. Graves, Associate Design Engineer II Mechanisms Engineering

Fluor Daniel Northwest

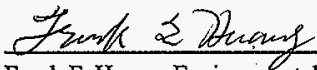

Frank F. Huang, Environmental Engineer/Scientist Mechanisms Engineering

Fluor Daniel Northwest

Approved By:

$$
R E R \text { men }
$$

Roy E. Russell Jr., Manager Mechanisms Engineering Fluor Daniel Northwest

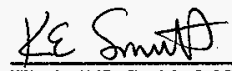

Kimball E. Smith, MCO Subproject Lead

SNF Storage Projects

Duke Engineering \& Services Hanford

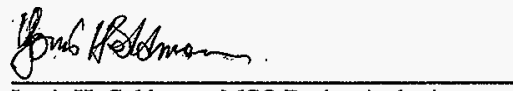

Louis H. Goldmann, MCO Design Authority

SNF Storage Projects

Duke Engineering \& Services Hanford
$09 / 25 / 97$

Date

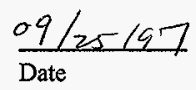

$2 / 25 / 42$ Date

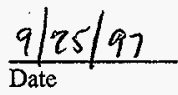


EVALUATION OF COPPER FOR DIVIDER SUBASSEMBLY IN

MCO MARK 1A AND MARK IV SCRAP FUEL BASKETS

\section{TABLE OF CONTENTS}

ABBREVIATIONS AND ACRONYMS $\ldots \ldots \ldots \ldots \ldots \ldots \ldots \ldots \ldots \ldots \ldots \ldots \ldots \ldots$

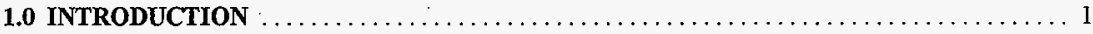

2.0 SUMMARY $\ldots \ldots \ldots \ldots \ldots \ldots \ldots \ldots \ldots \ldots \ldots \ldots \ldots \ldots \ldots \ldots \ldots \ldots \ldots \ldots \ldots \ldots \ldots$

3.0 MCO SCRAP FUEL BASKETS DESCRIPTION $\ldots \ldots \ldots \ldots \ldots \ldots \ldots \ldots \ldots \ldots \ldots \ldots \ldots 2$

4.0 MCO PROCESS BACKGROUND $\ldots \ldots \ldots \ldots \ldots \ldots \ldots \ldots \ldots \ldots \ldots \ldots \ldots \ldots \ldots$

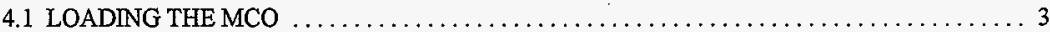

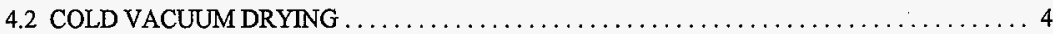

4.3 HOT CONDITIONING SYSTEM $\ldots \ldots \ldots \ldots \ldots \ldots \ldots \ldots \ldots \ldots \ldots \ldots \ldots \ldots \ldots \ldots \ldots 4$

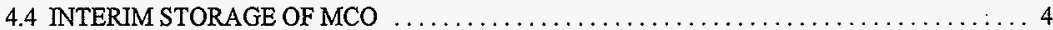

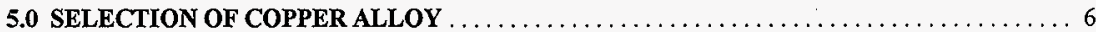

6.0 COPPER CORROSION RESISTANCE $\ldots \ldots \ldots \ldots \ldots \ldots \ldots \ldots \ldots \ldots \ldots \ldots \ldots \ldots \ldots$

6.1 DURNG STORAGE PRIOR TOUSAGE $\ldots \ldots \ldots \ldots \ldots \ldots \ldots \ldots \ldots \ldots \ldots \ldots \ldots$

6.2 MCO CONTAINING LIQUID WATER $\ldots \ldots \ldots \ldots \ldots \ldots \ldots \ldots \ldots \ldots \ldots \ldots \ldots \ldots \ldots$

6.3 MCO DURING REMOVAL OF LIQUID WATER $\ldots \ldots \ldots \ldots \ldots \ldots \ldots \ldots \ldots \ldots \ldots \ldots \ldots$

6.4 MCO AFTER REMOVAL OF LIQUID WATER $\ldots \ldots \ldots \ldots \ldots \ldots \ldots \ldots \ldots \ldots \ldots \ldots$.

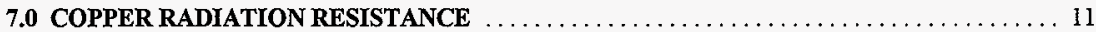

8.0 MCO THERMAL TRANSIENT EFFECTS $\ldots \ldots \ldots \ldots \ldots \ldots \ldots \ldots \ldots \ldots \ldots \ldots \ldots \ldots$

9.0 BRAZE MATERIAL CORROSION RESISTANCE $\ldots \ldots \ldots \ldots \ldots \ldots \ldots \ldots \ldots \ldots \ldots$

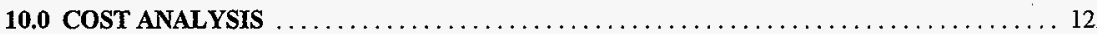

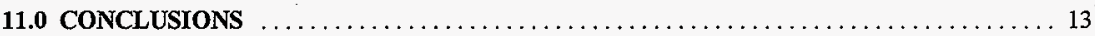

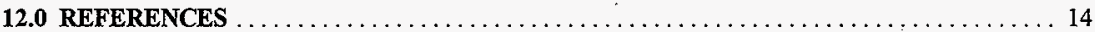

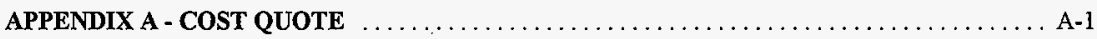




\section{LIST OF TABLES}

Page

1: Dimensions of Main Scrap Basket Components $\ldots \ldots \ldots \ldots \ldots \ldots \ldots \ldots \ldots \ldots \ldots \ldots \ldots \ldots$

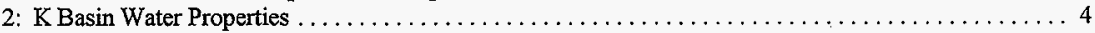

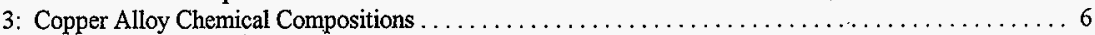

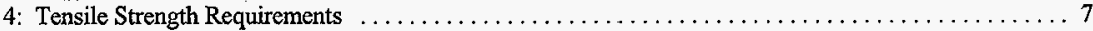

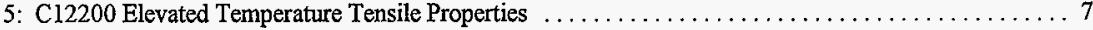

6: C10200 Elevated Temperature Tensile Properties $\ldots \ldots \ldots \ldots \ldots \ldots \ldots \ldots \ldots \ldots \ldots \ldots \ldots$

7: Copper Thermal Expansion Coefficients $\ldots \ldots \ldots \ldots \ldots \ldots \ldots \ldots \ldots \ldots \ldots \ldots \ldots \ldots \ldots . \ldots \ldots$

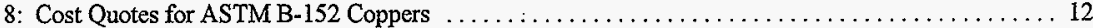

\section{LIST OF FIGURES}

1: MCO Hot Conditioning Temperature Cycle $\ldots \ldots \ldots \ldots \ldots \ldots \ldots \ldots \ldots \ldots \ldots \ldots \ldots \ldots$ 


\section{. ABBREVIATIONS AND ACRONYMS}

$\begin{array}{ll}\text { Ag } & \text { Silver } \\ \text { AISI } & \text { American Iron and Steel Institute } \\ \text { ASME } & \text { American Society of Mechanical Engineers } \\ \text { ASTM } & \text { American Society for Testing \& Materials } \\ \text { B\&PV } & \text { Boiler and Pressure Vessel (Code) } \\ \text { CSB } & \text { Canister Storage Building } \\ \text { Cu } & \text { Copper } \\ \text { CVD } & \text { Cold Vacuum Drying } \\ \text { FRS } & \text { Fuel Retrieval System } \\ \text { HCS } & \text { Hot Conditioning System } \\ \text { HCSE } & \text { Hot Condition System Equipment } \\ \text { KE } & \text { KEast Basin } \\ \text { ksi } & \text { kilopound/in }{ }^{2}=1000 \text { psi (lb/in }{ }^{2} \text { ) } \\ \text { KW } & \text { K West Basin } \\ \text { MCO } & \text { Multi-Canister Overpack } \\ \text { mil } & \text { 0.001 in. } \\ \text { Ni } & \text { Nickel } \\ \text { O } & \text { Oxygen } \\ \text { OD } & \text { Outside diameter } \\ \text { P } & \text { Phosphorus } \\ \text { PCB } & \text { Polychlorinated biphenyl } \\ \text { SCC } & \text { Stress corrosion cracking } \\ \text { SNF } & \text { Spent Nuclear Fuel } \\ \text { SS } & \text { Stainless steel } \\ \text { UNS } & \text { Unified Numbering System } \\ & \end{array}$




\section{EVALUATION OF COPPER FOR DIVIDER SUBASSEMBLY IN MCO MARK 1A AND MARK IV SCRAP FUEL BASKETS}

\section{1..0 INTRODUCTION}

The K Basin Spent Nuclear Fuel (SNF) Project Multi-Canister Overpack (MCO) subproject includes the design and fabrication of a canister that will be used to confine, contain, and maintain fuel in a critically safe array to enable its removal from the K Basins, vacuum drying, transport, staging, hot conditioning, and interim storage (Goldmann 1997). Each MCO consists of a shell, shield plug, fuel baskets (Mark 1A or Mark IV), and other incidental equipment.

The Mark 1A intact and scrap fuel baskets are a safety class item for criticality control and components necessary for criticality control will be constructed from $304 \mathrm{~L}$ stainless steel. It is proposed that a copper divider subassembly be used in both Mark 1A and Mark IV scrap baskets to increase the safety basis margin during cold vacuum drying. The use of copper would increase the heat conducted away from the fuel fines areas in the baskets out to the wall of the MCO by both radiative and conductive heat transfer means. This copper subassembly will likely be a safety significant component of the scrap fuel baskets. This report examines the structural, cost and corrosion consequences associated with using a copper subassembly in the stainless steel MCO scrap fuel baskets.

\subsection{SUMMARY}

Three copper alloys (ASTM B152) were examined for use as alternatives to 304L stainless steel in constructing the Mark IA and Mark IV scrap baskets divider subassembly:

- C10200, an oxygen-free copper without residual deoxidants;

- $\mathrm{Cl} 10800$, an oxygen-free low phosphorus copper; and

- C12200, a phosphorized, high residual phosphorus copper

The room temperature mechanical properties depend upon temper and can approximate those of $304 \mathrm{~L}$ stainless steel at the higher-hardness tempers. C10200 and C10800 have the highest electrical and thermal conductivity while $\mathrm{C} 12200$ is about $15 \%$ lower. Elevated temperature yield strength of $\mathrm{C1} 2200$ is only slightly lower than stainless steel, but the tensile strength is only about one-third that of the stainless steel. The $\mathrm{C} 10200$ and $\mathrm{C} 10800$ coppers have 5 to $15 \%$ lower elevated temperature strength levels. The coppers are prone to stress relaxation but the addition of minute amounts of silver significantly reduce the effects. Thermal expansion coefficients for the coppers are 5-10\% larger than stainless steel.

Corrosion resistance of the coppers in the MCO environments are acceptable and approximately equal among the alloys; none are prone to hydrogen embrittlement or stress corrosion cracking.

Cost quotes showed $\mathrm{Cl} 2200$ to be about $7 \%$ less than $\mathrm{C} 10200$. C10800 is not readily available and would be more expensive as it is a special order alloy. Fabrication costs would be similar for both $\mathrm{C} 10200$ and $\mathrm{C} 12200$. 


\subsection{MCO SCRAP FUEL BASKETS DESCRIPTION}

The MCO assembly is a single purpose SNF container that is capable of maintaining SNF subcritical at all times and maintaining SNF containment after having been closed and sealed (Goldmann 1996). The $\mathrm{MCO}$ is designed for a 40 year lifetime (extendable to 75 years) with a design pressure of $1.0 \mathrm{MPa}$ ( 150 psig) and a maximum temperature of $375^{\circ} \mathrm{C}\left(707^{\circ} \mathrm{F}\right)$. The $\mathrm{MCO}$ assembly consists of three parts: shell, shield plug and Mark 1A or Mark IV fuel baskets (both intact and scrap). Both the shell and shield plug are constructed of 304L stainless steel. With the exception of the Mark IV fuel baskets, the MCO must be in accordance with the American Society of Mechanical Engineers (ASME) Boiler and Pressure Vessel (B\&PV) Code, Section III, Subsection NB (ASME 1995) with few exceptions. The copper divider subassembly has no ASME compliance requirements.

The scrap fuel baskets are anmular open-top containers with a maximum outside diameter (OD) of $57.5 \mathrm{~cm}(22.625 \mathrm{in}$.). There are two types of baskets, intact fuel element and scrap fuel (fragment) element. The baskets are designed such that only one fuel type (Mark 1A or Mark IV) will be loaded into each MCO. The baskets are designed to be stackable (in any order) inside the MCO with the basket centerline coinciding with the MCO centerline. The Mark 1A fuel baskets are sized such that there are six baskets per MCO. The increased height of the Mark IV fuel baskets allows only five baskets per MCO.

Both Mark IA and Mark IV scrap baskets are of a perforated cylindrical plate design attached to a center post. The perforations support gas flows needed to properly $d r y$ and condition the fuel during the vacuum drying and hot conditioning processes. The center post provides axial and lateral support for the baskets and also accommodates miscellaneous process tubing. The copper divider subassembly resembles a donut with an inner tube (fines divider tube) connected to an outer tube (shroud) by six equidistant divider plates. Stainless steel support rods along the inner diameter of the shroud provide stability and prevent basket collapse. The copper divider subassembly is attached to the 304L stainless steel basket base plate by a mechanical joint. Some construction changes may occur as the basket design is still in evolution.

The Mark IA fuel baskets must maintain criticality control as the Mark 1A fuel has a higher $U_{235}$ enrichment than the Mark IV fuel. Accordingly, the Mark IA baskets have a larger center post (to provide the criticality control) which affects the inner diameter of the divider subassembly. Table 1 lists the dimensions of the main pieces for both the Mark IA and Mark IV baskets. The fines inner tube and the shroud are constructed from plate or sheet and silver brazed (see Section 9.0 for corrosion resistance of the braze filler material). For more details on the Mark IA and Mark IV scrap fuel baskets see drawings H-2828065 (DESH 1997A) and H-2-828075 (DESH 1997B), respectively.

The copper-to-copper joints in the divider subassembly will be furnace brazed using BCuP-5 filler material $(15 \% \mathrm{Ag}, 80 \% \mathrm{Cu}, 5 \% \mathrm{P})$. BCuP-5 has a liquidus temperature of $800^{\circ} \mathrm{C}\left(1472^{\circ} \mathrm{F}\right)$ (Beal and Cook 1993). Brazing normally takes place at approximately $28^{\circ} \mathrm{C}\left(50^{\circ} \mathrm{F}\right)$ higher than the filler material liquidus temperature, in this case, about $828^{\circ} \mathrm{C}\left(1522^{\circ} \mathrm{F}\right)$.

\footnotetext{
¥ The copper subassembly is not needed to maintain criticality control.
} 
Table 1: Dimensions of Main Scrap Basket Components (DESH 1997A and 1997B)

\begin{tabular}{|c|c|c|}
\hline \multirow{2}{*}{ Part } & \multicolumn{2}{|c|}{ Part Sixe } \\
\hline & Mark 1A Serap Basket & Mark IV Scrap Basket \\
\hline Center Post* & $\begin{array}{l}15.24 \mathrm{~cm}(6 \mathrm{in} .) \varnothing \text { pipe, } \\
2.19 \mathrm{~cm}(0.864 \text { in. }) \text { wall }\end{array}$ & $\begin{array}{c}6.98 \mathrm{~cm}(2.75 \mathrm{in} .) \otimes \text { pipe, } \\
1.27 \mathrm{~cm}(0.5 \mathrm{in} .) \text { wall }\end{array}$ \\
\hline Base Plate* & $\begin{array}{l}57.47 \mathrm{~cm}(22.625 \mathrm{in} .) \theta \\
2.86 \mathrm{~cm}(1.125 \mathrm{in}) \text { thick }\end{array}$ & $\begin{array}{l}57.47 \mathrm{~cm}(22.625 \mathrm{in} .) \oslash \\
3.18 \mathrm{~cm}(1.25 \mathrm{in} .) \text { thick }\end{array}$ \\
\hline Support Rods* & $\begin{array}{c}7.75 \mathrm{~cm} \times 3.43 \mathrm{~cm} \text { [trapezoid] } \\
(3.053 \text { in. } \times 1.351 \text { in. })\end{array}$ & $3.21 \mathrm{~cm}(1.2625 \mathrm{in}) \otimes \mathrm{bar}$ \\
\hline Fines Divider Tube** & $\begin{array}{c}23.37 \mathrm{~cm}(9.2 \mathrm{in} .) \theta \\
0.32 \mathrm{~cm}(0.125 \mathrm{in} .) \text { wall }\end{array}$ & $\begin{array}{c}19.94 \mathrm{~cm}(7.85 \mathrm{in} .) \varnothing \\
0.32 \mathrm{~cm}(0.125 \mathrm{in} .) \text { wall }\end{array}$ \\
\hline Outer Shroud** & $\begin{array}{l}57.47 \mathrm{~cm}(22.625 \mathrm{in} .) \ominus, \\
0.32 \mathrm{~cm}(0.125 \mathrm{in} .) \text { wall }\end{array}$ & $\begin{array}{l}57.47 \mathrm{~cm}(22.625 \mathrm{in} .) \theta_{0} \\
0.32 \mathrm{~cm}(0.125 \mathrm{in} .) \text { wall }\end{array}$ \\
\hline Divider Plate** & $\begin{array}{c}16.38 \mathrm{~cm} \times 54.23 \mathrm{~cm} \\
(6.45 \mathrm{in} \times 21.35 \mathrm{in} .) \\
0.64 \mathrm{~cm}(0.25 \mathrm{in} .) \text { thick }\end{array}$ & $\begin{array}{c}18.44 \mathrm{~cm} \times 66.68 \mathrm{~cm} \\
(7.26 \mathrm{in} \times 26.25 \mathrm{in} .) \\
0.64 \mathrm{~cm}(0.25 \mathrm{in} .) \text { thick }\end{array}$ \\
\hline
\end{tabular}

* Constructed from $304 \mathrm{~L}$ stainless steel

** Constructed from brazed copper sheet

\section{4..0 MCO PROCESS BACKGROUND}

The Integrated Process Strategy For Spent Nuclear Fuel Project Facilities recommended the following path forward for the removal of materials from the $\mathrm{K}$ basin:

- desludge and clean the SNF;

- repackage the cleaned SNF into fuel baskets;

- load the fuel baskets into MCOs;

- cold vacuum dry (CVD) the loaded MCOs at the CVD Facility;

- transport the loaded MCOs to the CSB;

- hot condition (additional drying, dehydriding and dehydrating) at a CSB annex facility; and

- transfer MCOs into storage tubes at the CSB for interim dry storage awaiting final disposition.

Fuel movement is currently scheduled to start July 30,1999 and continue for two years. The total number of MCOs to be processed is approximately 200 from K East (KE) basin and 200 from K West (KW) basin (O'Neill 1996B). The following sections are reprinted from a companion report on MCO fuel basket material selection (Graves 1997). Process descriptions and steps presented below are approximate and may change as each step's design is completed.

\section{a. LOADING THE MCO}

Once cleaned, the $\mathrm{K}$ basin SNF is loaded underwater into the fuel baskets by the fuel retrieval system (FRS). The properties of the $\mathrm{K}$ Basin water are shown in Table 2. While still submerged, the loaded fuel baskets are then inserted into the MCO shell: The MCO is temporarily sealed with some water removed prior to shipment (fuel remains flooded) of the $\mathrm{MCO} /$ cask assembly to the cold vacuum drying facility. 
Table 2: K Basin Water Properties (Goldmann 1997)

\begin{tabular}{|l|lr||}
\hline Temperature & 6 to $38^{\circ} \mathrm{C}\left(43\right.$ to $\left.100^{\circ} \mathrm{F}\right)$ \\
\hline$p H$ & 5.5 to 7.5 (Current range) \\
\hline Conductivity & $\mathrm{KE}: \leq 5 \mu \mathrm{S} / \mathrm{cm}$ & $\mathrm{KW}: \leq 2 \mu \mathrm{S} / \mathrm{cm}$ \\
\hline Mineral Content & Chloride: $<1 \mathrm{ppm}$ & Nitrate: $<1 \mathrm{ppm}$ \\
& Sulfate: $<1 \mathrm{ppm}$ & Phosphate: $<1 \mathrm{ppm}$ \\
& Fluoride: $0.25 \mathrm{ppm}$ & Sodium: $1 \mathrm{ppm}$ \\
& Calcium: $2 \mathrm{ppm}$ & Iron: $1 \mathrm{ppm}$ \\
\hline
\end{tabular}

\subsection{COLD VACUUM DRYING}

Cold vacuum drying (CVD) drains the bulk water and vacuum dries the SNF inside the MCO prior to transportation from the CVD Facility to the CSB (O'Neill 1996B). Prior to drying, bulk water is drained from the MCO via a long axial dip tube while the MCO temperature is held below $50^{\circ} \mathrm{C}\left(122^{\circ} \mathrm{F}\right)$. An inert gas purge of helium aids in draining the bulk water.

Drying of the SNF is performed by heating the $\mathrm{MCO}$ to $50^{\circ} \mathrm{C}\left(122^{\circ} \mathrm{F}\right)$ for 48 hours. A vacuum pumping system removes any gases from the MCO during drying (i.e., offgassing, residual free water, inleakage, etc.). Following fuel drying, the MCO is backfilled with approximately $99.95 \%$ purity helium to $400 \mathrm{~Pa}(0.06 \mathrm{psi})$ and temporarily sealed. The $\mathrm{MCO}$ is then heated to $75^{\circ} \mathrm{C}\left(167^{\circ} \mathrm{F}\right)$ for 6 hours to monitor for any pressure buildup (shipping simulation temperature). Following monitoring, the MCO is cooled to $15^{\circ} \mathrm{C}\left(59^{\circ} \mathrm{F}\right)$ and prepared for shipment to the CSB to await hot conditioning.

\subsection{HOT CONDITIONING SYSTEM}

The Hot Conditioning System (HCS) removes chemically bound water from the SNF (O'Neill 1996A). This process also minimizes the potential for subsequent pressurization of the sealed MCO by removing constituents that can change phase to a gaseous state under storage conditions (Garvin 1997). The HCS is performed by the hot condition system equipment (HCSE) which will be located in an annex of the CSB. At this time, the design and procurement of the HCS is on hold pending review.

The hot conditioning cycle takes approximately six days to complete; temperature levels for the different stages of the cycle are shown in Figure 1. Gas purging of the MCO is performed in conjunction with the heating to remove unwanted gases (chemically bound water, fission gases, air, etc.) and to maintain the hydrogen concentration below 2 volume percent. During the backfill stage, the MCO is filled with approximately $99.95 \%$ purity helium to a gauge pressure of $21-50 \mathrm{kPa}(3-7.3 \mathrm{psi})$ and sealed for storage. Once conditioned, the $\mathrm{MCO}$ is not expected to need venting during interim dry storage at the CSB (Garvin 1997). However, a pressure relief device will be active at all times in the unexpected event of MCO overpressurization.

\subsection{INTERIM STORAGE OF MCO}

After sealing, the $\mathrm{MCO}$ /cask assembly returns to the CSB for dry interim storage until a suitable longterm repository can be established. Expected storage temperatures at the CSB are -10 to $132{ }^{\circ} \mathrm{C}(14$ to $270^{\circ} \mathrm{F}$ ). 
Figure 1: MCO Hot Conditioning Temperature Cycle (O'Neill 1996A)

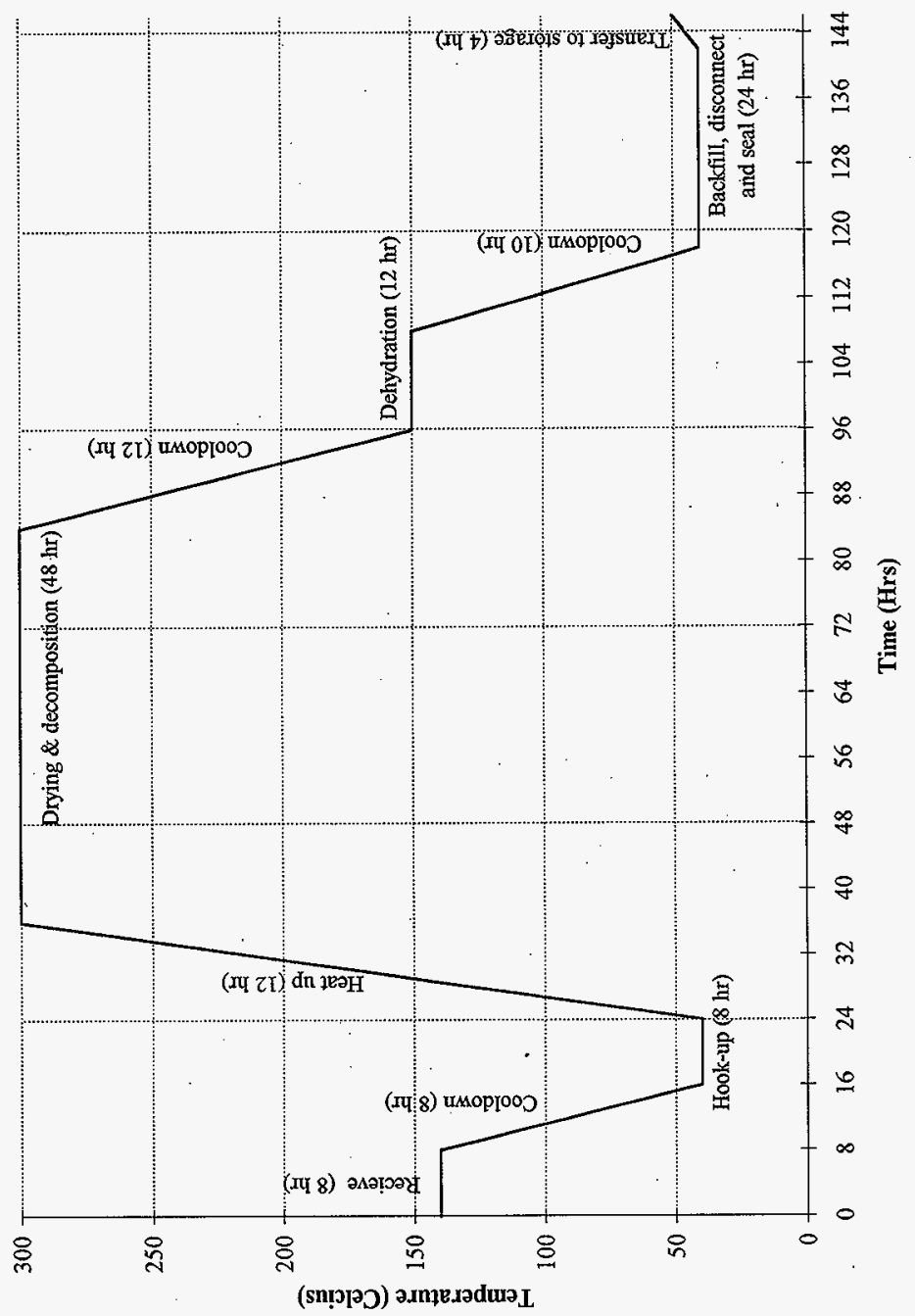




\subsection{SELECTION OF COPPER ALLOY}

Copper and its alloys have found exclusive applications where combinations of excellent electrical and/or thermal conductivity, excellent formability, moderate strength, and good corrosion resistance are required (Chawla and Gupta 1993). The wrought alloys examined in this report all fall into the same copper family, coppers, which have a designated minimum copper content of $99.3 \%$ and the best thermal conductivity values of copper alloys. These alloys were chosen in order to maintain low oxygen levels to minimize the detonation potential of hydrogen in the MCO.

The chemical composition of the three coppers, as specified by ASTM standard B-152 (ASTM 1997) for copper plate and sheet, is listed in Table 3 . C10200 is a high conductivity copper produced by melting and casting in an oxygen-free atmosphere thus preventing oxygen from entering the copper. The addition of phosphorus ( $\mathrm{C} 10800$ and $\mathrm{C} 12200$ coppers) converts available oxygen in the copper to phosphorus pentoxide $\left(\mathrm{P}_{2} \mathrm{O}_{5}\right)$. The low residual phosphorus in the $\mathrm{C} 10800$ copper maintains the electrical conductivity of copper. High residual phosphorus, $\mathrm{Cl} 2200$ copper, lowers electrical conductivity by about $15 \%$, yet it improves coldworking properties and prevents the adsorption of oxygen at the high temperatures used for forming and welding.

Table 3: Copper Alloy Chemical Compositions (ASTM 1997)

\begin{tabular}{||c|c|c|c|}
\hline UNS* No. & Type of Coppers & Min wt \% Cu** & Other \\
\hline C10200 & Oxygen-free without residual deoxidants (OF) & 99.95 & 10 ppm O (max) \\
\hline C10800 & Oxygen-free, low phosphorus & 99.95 & $0.005-0.012 \mathrm{wt} \% \mathrm{P}$ \\
\hline C12200 & Phosphorized, high residual phosphorus (DHP) & 99.90 & $0.015-0.040 \mathrm{wt} \% \mathrm{P}$ \\
\hline
\end{tabular}

* Unified Numbering System

** Includes silver

Table 4 lists the ASTM standard required tensile properties of the three coppers based upon the temper designation. At a $\mathrm{H} 04$ temper, the copper tensile strength value is about $60 \%$ of the comparable $304 \mathrm{~L}$ stainless steel value (ASME 1995). The yield strength varies from about 69 to $360 \mathrm{MPa}$ (10 to $53 \mathrm{ksi}$ ) depending upon temper (Robinson 1990). Elongation values (in $50 \mathrm{~mm}$ [2 in.]) for the coppers will vary from 5 to $55 \%$ with the higher values associated with the lower strengths (Robinson 1990). An H04 temper yields elongations values of 10 to $20 \%$, depending upon material thickness (Robinson 1990).

The short time elevated temperature tensile properties of a C12200 copper are presented in Table 5 . Similar data for a $\mathrm{C} 10200$ copper are listed in Table 6.(data was not available at the higher temperatures). As compared to the $\mathrm{C} 12200$ data, the $\mathrm{C} 10200$ tensile and yield strengths are about $5 \%$ and $15 \%$ lower, respectively. The $\mathrm{C} 10800$ copper is expected to behave similar to the $\mathrm{C} 10200$ copper at elevated temperatures. Note that at the maximum MCO temperature, $375^{\circ} \mathrm{C}\left(707^{\circ} \mathrm{F}\right)$, the yield and tensile strengths of $\mathrm{C} 12200$ are about $55 \%$ of their room temperature values (percentages for $\mathrm{C} 10200$ and $\mathrm{C} 10800$ are even lower $)^{\ddagger}$. At this temperature, the copper yield strength is only about $5 \%$ less than the $304 \mathrm{~L}$ stainless steel; however, the copper tensile strength is $70 \%$ less than that of the 304L (ASME 1995). Since the C12200

$\ddagger$ When temperatures exceed $375^{\circ} \mathrm{C}\left(707^{\circ} \mathrm{F}\right)$ the low end of the annealing range of the coppers is reached (Robinson. 1990). This initiates recrystallization and softening of the metal (usually done to prepare to metal for further cold working). 
copper yield strength is comparable to that of 304L stainless steel, slumping during hot conditioning should not be a problem. However, a simple stress analysis should be performed to determine structural integrity during impact scenarios (i.e., fuel or manipulator impact). As brazing temperatures will cause some recrystallization and softening, a temper of at least $\mathrm{H} 04$ (hard) should be used to maximize strength properties during hot conditioning.

Table 4: Tensile Strength Requirements (ASTM 1997)

\begin{tabular}{||c|c|c|c||}
\hline \multicolumn{2}{|c|}{ Temper Designation } & \multicolumn{2}{c|}{ Tensile Strength } \\
\hline Standard & Former & Min, MPa (ksi) & Max, MPa (ksi) \\
\hline H00 & $1 / 6$ hard & $221(32)$ & $276(40)$ \\
\hline H01 & $1 / 4$ hard & $234(34)$ & $290(42)$ \\
\hline H02 & $1 / 2$ hard & $255(37)$ & $317(46)$ \\
\hline H03 & 3/4 hard & $283(41)$ & $345(50)$ \\
\hline H04 & hard & $296(43)$ & $359(52)$ \\
\hline H06 & Extra hard & $324(47)$ & $386(56)$ \\
\hline H08 & Spring & $345(50)$ & $400(58)$ \\
\hline H10 & Extra Spring & $359(52)$ &.$\cdots$ \\
\hline M20 & Hot-rolled & $207(30)$ & $262(38)$ \\
\hline O25 & Hot-rolled and annealed & $207(30)$ & $262(38)$ \\
\hline
\end{tabular}

Table 5: C12200 Elevated Temperature Tensile Properties (Upthegrove and Burghoff 1956) Temper: Hot-rolled and annealed at $621^{\circ} \mathrm{C}\left(1150^{\circ} \mathrm{F}\right)$ then cold-rolled $5-7 \%$

\begin{tabular}{|c|c|c|c|c|c|c|c|}
\hline \multicolumn{2}{|c|}{ Test Temperature } & \multirow{2}{*}{$\begin{array}{c}\text { Elastic } \\
\text { Modulus } \\
\text { GPa }\left(10^{3} \text { ksi) }\right.\end{array}$} & \multicolumn{2}{|c|}{ Tensile Strength } & \multicolumn{2}{|c|}{ Yield Strength* } & \multirow{2}{*}{$\begin{array}{l}\% \text { Elongation in } \\
50 \mathrm{~mm}(2 \mathrm{in} .)\end{array}$} \\
\hline${ }^{\circ} \mathbf{C}$ & ${ }^{\circ} \mathbf{F}$ & & $\mathbf{M P a}$ & ksi & $\mathbf{M P a}$ & ksi & \\
\hline 24 & 75 & $114(16.6)$ & 229 & 33.2 & 174 & 25.3 & 52.0 \\
\hline 60 & 140 & $109(15.8)$ & 217 & 31.5 & 161 & 23.4 & 50.9 \\
\hline 100 & 212 & $119(17.2)$ & 203 & 29.5 & 171 & 24.8 & 45.4 \\
\hline 149 & 300 & $108(15.7)$ & 189 & 27.4 & 151 & 21.9 & 46.8 \\
\hline 204 & 400 & $102(14.8)$ & 174 & 25.2 & 152 & 22.1 & 46.5 \\
\hline 288 & 550 & $103(15.0)$ & 150 & 21.7 & 117 & 17.0 & 49.6 \\
\hline 371 & 700 & $74(10.8)$ & 121 & 17.6 & 97 & 14.1 & 57.8 \\
\hline 454 & 850 & $55(8.0)$ & 71 & 10.3 & 91 & 13.2 & 68.0 \\
\hline
\end{tabular}


Table 6: C10200 Elevated Temperature Tensile Properties (Upthegrove and Burghoff 1956) Temper: cold-rolled 5-7\%

\begin{tabular}{|c|c|c|c|c|c|c|c|}
\hline \multicolumn{2}{|c|}{ Test Temperature } & \multirow{2}{*}{$\begin{array}{c}\text { Elastic } \\
\text { Modulus } \\
\text { GPa }\left(10^{3} \mathrm{ksi}\right)\end{array}$} & \multicolumn{2}{|c|}{ Tensile Strength } & \multicolumn{2}{|c|}{ Yield Strength* } & \multirow{2}{*}{$\begin{array}{l}\text { \% Elongation in } \\
50 \mathrm{~mm}(2 \mathrm{in} \text {.) }\end{array}$} \\
\hline${ }^{\circ} \mathbf{C}$ & ${ }^{\circ} \mathbf{F}$ & & MPa & ksi & $\mathrm{MPa}$ & ksi & \\
\hline 24 & 75 & $116(16.8)$ & 218 & 31.6 & 153 & 22.2 & 50.7 \\
\hline 100 & 212 & $117(16.9)$ & 195 & 28.3 & 147 & 21.3 & 46.8 \\
\hline 204 & 400 & $98(14.2)$ & 165 & 23.9 & 130 & 18.8 & 45.6 \\
\hline
\end{tabular}

At room and elevated temperatures, copper and its alloys are susceptible to stress-relaxation, the decrease of internal stress over time. For example, upon heating a $0.25 \mathrm{~mm}(0.01 \mathrm{in}$.) diameter $\mathrm{C} 11000$ annealed wire with an initial stress of $89 \mathrm{MPa}(13 \mathrm{ksi})$ to $149^{\circ} \mathrm{C}\left(300^{\circ} \mathrm{F}\right)$, only about $25 \%$ of the initial stress remained after 100 hours (Tyler 1990, Figure 11). The stress-relaxation data for $\mathrm{C} 10200$ are somewhat better. The addition of minute amounts of silver $(<0.08 \%)$ significantly reduces the stress relaxation effects in copper (Tyler 1990) and is strongly recommended in this application.

The thermal expansion coefficients for the coppers are shown in Table 7. These values would apply to all three coppers because of the very small amounts of alloying elements. In comparison to stainless steel, the copper values are only $5-10 \%$ larger. This difference is small enough and the basket design is such that expansion problems during hot conditioning should not occur.

Table 7: Copper Thermal Expansion Coefficients (Robinson 1990)

\begin{tabular}{|c|c|c|c||}
\hline \multicolumn{2}{|c|}{ Temperature Range } & \multicolumn{2}{c|}{$\begin{array}{c}\text { Mean Coefficient of } \\
\text { Thermal Expansion }\end{array}$} \\
\hline${ }^{\circ} \mathbf{C}$ & ${ }^{\circ} \mathbf{F}$ & $\times 10^{-6}\left({ }^{\circ} \mathbf{C}^{-1}\right.$ & $\times 10^{-6}\left({ }^{\circ} \mathbf{F}\right)^{-1}$ \\
\hline $20-100$ & $68-212$ & 17.0 & 9.4 \\
\hline $20-200$ & $68-392$ & 17.3 & 9.6 \\
\hline $20-300$ & $68-572$ & 17.7 & 9.8 \\
\hline
\end{tabular}

\subsection{COPPER CORROSION RESISTANCE}

Copper and its alloys are corrosion resistant because they are inherently "noble" by virtue of their low driving force toward the oxidized state as measured by the electromotive force series and also because of the formation of adherent impervious films of corrosion product in various media (Lyman 1980). As the three coppers vary only slightly in composition, their corrosion resistance will also be similar (any differences are noted).

Only certain specific environments appear to produce stress corrosion of copper alloys, notably ammonia $\left(\mathrm{NH}_{3}\right)$ or ammonium $\left(\mathrm{NH}_{4}^{+}\right)$compounds or related compounds such as amines (Gilbert 1994). As none of these environments are expected within the $\mathrm{MCO}$, stress corrosion cracking (SCC) of the copper divider subassembly is not a factor. 


\subsection{DURING STORAGE PRIOR TO USAGE}

Prior to actual fuel loading, the fuel baskets will need to be stored, most likely in a combination of dry (warehouse) and wet (basin) conditions. The Hanford site falls into an arid rural atmospheric corrosion category due to its dry desert atmosphere with a relative absence of industrial pollutants. Atmospheric corrosion of two coppers, 110 and 120 , were measured (Polan 1987) to be less than $0.13 \mu \mathrm{m} / \mathrm{yr}$ $(0.005 \mathrm{mils} / \mathrm{yr})$ in an arid rural environment (Phoenix, Arizona) similar to the Hanford site. Corrosion rates for the $\mathrm{C} 10200, \mathrm{Cl} 10800$ or $\mathrm{Cl} 2200$ coppers would be similar.

Minerals in water combine with dissolved $\mathrm{CO}_{2}$ and oxygen and react with copper to form a protective film. In distilled or very soft water, protective films are less likely to form; the corrosion rate may vary from less than 2.5 to $125 \mu \mathrm{m} / \mathrm{yr}\left(0.1\right.$ to $5 \mathrm{mils} / \mathrm{yr}$ ) or more, depending on oxygen and $\mathrm{CO}_{2}$ content (Polan 1987). Even at the higher corrosion rate, impact to the divider subassembly would be minimal due to the relatively short ( $\ll 1$ year) exposure times.

\subsection{MCO CONTAINING LIQUID WATER}

The resistance of the copper alloys to water is discussed in the previous section.

As water can function as an electrolytic conductor, the potential for galvanic corrosion must be examined. The main dissimilar metal contact scenario within the $\mathrm{MCO}$ is contact between the copper divider subassembly and the 304L stainless steel baskets and shell. Both copper and stainless steel exhibit passive oxide layers on their surfaces. In comparison, passive stainless steel is more noble (corrosion-resistant) than copper in the sea water galvanic series ${ }^{\ddagger}$. This results in an accelerated galvanic corrosion of the copper. As there will only be one scrap basket loaded into each $\mathrm{MCO}$, the area ratio of stainless steel to copper is very large, acting to increase the copper corrosion rate even more ${ }^{t \ddagger}$. The driving force for this galvanic corrosion will be appreciably lessened due to the much lower conductivity of the $K$ basin water (versus sea water) and the relatively small spread between copper and stainless steel in the galvanic series.

There are three other possible dissimilar metal contact scenarios within the MCO which could result in accelerated galvanic corrosion of the copper divider subassembly:

1) Contact with Zircaloy-2 fuel cladding - The zirconium-based cladding forms a passive oxide surface

film that is more noble than the copper oxide layer. Thus, accelerated galvanic corrosion of the copper will occur.

2) Contact with aluminum fuel cladding $\$ \$$ _- The aluminum cladding also forms a protective oxide coating, however, this coating is less noble than the copper oxide layer. In this case, accelerated corrosion of the aluminum would occur.

3) Contact with uranium fuel -- The uranium is actively corroding with a nonprotective oxide layer resulting in no accelerated corrosion of the copper.

The lower water conductivity will diminish the above mentioned galvanic reactions such that avoiding direct contact with the above materials is not required.

$\ddagger$ Copper can accelerate corrosion of active stainless steel, particularly in highly chlorinated water. However, as chloride levels of the $\mathrm{K}$ Basin water are very low and stainless steel is easily passivated, this scenario is not expected.

\$ Filling an $\mathrm{MCO}$ with more than one scrap basket would reduce the stainless steel/copper area ratio thus reducing the magnitude of the copper corrosion rate increase.

\$t Some of the fuel elements have aluminum cladding instead of Zircaloy-2 cladding. 
The time period during which a loaded MCO is immersed in or is filled with liquid water is less than 2 days (Garvin 1997). Even with accelerated galvanic corrosion effects, this is an insufficient time period for significant corrosion of the copper divider subassembly to occur. However, should a problem occur during processing causing a backlog, storage of a flooded MCO should be limited to less than 6 months to prevent any corrosion product buildup from hampering process flow paths.

\subsection{MCO DURING REMOVAL OF LIQUID WATER}

Copper resists attack by pure steam, but if much $\mathrm{CO}_{2}$, oxygen, or $\mathrm{NH}_{3}$ is present, the condensate is corrosive (Polan 1987). Regular gas purging during drying will prevent the buildup of any of these gases.

Less than 48 hours is needed to remove liquid water from the MCO and establish a low water vapor pressure inside (WHC 1996). This period is too short to cause significant corrosion of the copper divider subassembly as there is no significant buildup of aggressive species. The low water vapor pressure, less than $66 \mathrm{~Pa}(0.01 \mathrm{psi})$, following cold vacuum drying prevents any condensation inside the MCO. Once the liquid water is removed and condensation is precluded, any liquid [galvanic] corrosion problems cease (Garvin 1997).

\subsection{MCO AFTER REMOVAL OF LIQUID WATER}

Following hot conditioning, there is the potential for four gases to exist within the MCO in addition to inert gases:

1) Hydrogen gas - Generated by reactions of the uranium fuel with water vapor or radiolysis of chemically bound water.

2) Chlorine gas - Produced by thermal or radiolytic decomposition of polychlorinated biphenyls (PCBs), detected in low levels in $\mathrm{K}$ basin sludge samples.

3) Iodine gas - Could be present due to the thermal environment and fuel corrosion.

4) Oxygen gas - Generated by the radiolysis of water.

A common form of hydrogen damage in copper is known as steam embrittlement and is observed only when copper contains oxygen. Hydrogen entering the metal reacts with the oxygen to form water; above $374^{\circ} \mathrm{C}\left(705^{\circ} \mathrm{F}\right)$ steam forms and the pressure generated is sufficient to produce microcavity formation and cracking. The use of oxygen-free coppers (C10200 and $\mathrm{C10800)}$ essentially eliminates susceptibility to steam embrittlement (Craig 1987). Deoxidized coppers with high residual deoxidizer contents (such as C12200) are not considered susceptible to hydrogen embrittlement because the oxygen is tied up in complex oxides that do not react appreciably with hydrogen (Polan 1987).

A maximum-use temperature of $205^{\circ} \mathrm{C}\left(400^{\circ} \mathrm{F}\right)$ is suggested for copper in dry chlorine (Liening 1987). Water vapor at room temperature accelerates attack of copper, however, above $250^{\circ} \mathrm{C}\left(480^{\circ} \mathrm{F}\right)$ water vapor and oxygen in chlorine reduce copper attack. However, PCBs are not expected in the $\mathrm{K}$ basin canister sludge, so they should not be present within the MCO. This, coupled with cleaning of the fuel prior to MCO loading and regular gas purging during processing, further reduces the possibility of chlorine gas corrosion problems. The fabrication specification (WHC 1996) also precludes the use of high halogen cleaners/materials in the MCO construction.

A literature search did not yield any recommendations concerning copper service in iodine gas. Since iodine is less aggressive than chlorine (assuming an equivalent partial pressure) and iodine levels are very low, corrosion attack of copper from iodine is unlikely. 
When copper is used at high temperatures in oxygen scaling results. Below $100^{\circ} \mathrm{C}\left(212^{\circ} \mathrm{F}\right)$, the oxide film increases in thickness logarithmically with time (Polan 1987). At medium temperatures the scaling rate increases following the parabolic law. Regular gas purging during hot conditioning will reduce or eliminate scaling of the copper.

In addition to gaseous corrosion reactions, contact between the copper divider subassembly and the fuel elements could cause liquid metal embrittlement by fuel fission products. Cesium and tin are the lower melting point fission products, less than $205^{\circ} \mathrm{C}\left(400^{\circ} \mathrm{F}\right)$, generated in the greatest amounts (Garvin 1997). Tin is reported to embrittle copper, while cesium does not (Nicholas 1984). However, as the tin and cesium levels in the fuel elements are low; content in a contact area would be far too small for significant damage of the divider subassembly to occur.

\section{7..0 COPPER RADIATION RESISTANCE}

Similar to aluminum, copper is hardened by irradiation. A literature search did not yield any quantitative information on the magnitude of irradiation hardening. This additional strength would aid in divider stability during the hot conditioning processing temperatures.

\subsection{MCO THERMAL TRANSIENT EFFECTS}

After drying of the MCO and on initial heat up, the fuel particulates inside the MCO will release water from crystalline forms. This free water vapor will then react with any bare uranium metal or hydrides to produce heat which may result in a thermal transient. The upper temperatures inside the MCO may then momentarily exceed $300^{\circ} \mathrm{C}\left(570^{\circ} \mathrm{F}\right)$. This generated a concern that the thermal transient temperatures could approach the eutectic (solid to liquid) temperature of the divider subassembly material.

Calculations performed by Thurgood (1997) showed that for the bounding case (staging) the peak fuel temperature was $443^{\circ} \mathrm{C}\left(830^{\circ} \mathrm{F}\right)$ and the peak MCO wall temperature was $261{ }^{\circ} \mathrm{C}\left(500^{\circ} \mathrm{F}\right)$. The calculations used the surface area and water inventory of the scrap fuel basket (worst case scenario) and the following assumptions: maximum sludge amount of $54.4 \mathrm{~kg}(120 \mathrm{lb})$, a water mass fraction of the sludge equal to or less than $10 \%$, and individual scrap pieces do not exceed $20 \%$ oxide. Calculations for shipping yielded lower peak temperatures than for staging (calculations for CVD are not yet complete). Both of these calculated peak temperatures fall well below the documented safety limit temperatures. The maximum $\mathrm{MCO}$ operational limit temperature is $375^{\circ} \mathrm{C}\left(700^{\circ} \mathrm{F}\right)$, as documented by Goldmann (1996). The maximum fuel safety limit temperature of $725^{\circ} \mathrm{C}\left(1340^{\circ} \mathrm{F}\right)$ is the uranium-iron eutectic temperature as documented in the MCO Topical Report (Garvin 1997).

The minimum eutectic transformation temperature is $1084.5^{\circ} \mathrm{C}\left(1984^{\circ} \mathrm{F}\right)$, equal to copper's melting point, for both the copper-iron and copper-nickel systems (ASM 1990). For the copper-uranium and copperzirconium systems the minimum eutectic transformation temperatures are slightly lower, $950^{\circ} \mathrm{C}\left(1742^{\circ} \mathrm{F}\right)$ and $885^{\circ} \mathrm{C}\left(1625^{\circ} \mathrm{F}\right)$, respectively. As all of the transformation temperatures are considerably above the calculated thermal transients, the likelihood of any copper eutectic reactions is negligible. 


\subsection{BRAZE MATERIAL CORROSION RESISTANCE}

The atmospheric, gaseous, and water corrosion resistance of the braze filler metal (BCuP-5) should be equal to or greater than that of the coppers. The addition of phosphorus will tie up any oxygen as $\mathrm{P}_{2} \mathrm{O}_{5}$, thus avoiding hydrogen embrittlement concerns. The addition of silver increases the filler material's galvanic corrosion resistance as it is more noble than either copper or stainless steel. Even with an unfavorable area ratio, this increased nobility will help protect the brazed areas from accelerated galvanic corrosion during the period when the MCO is immersed.

\subsection{COST ANALYSIS}

Three West Coast copper suppliers were contacted to obtain price information on the coppers:

- Alaskan Copper \& Brass; Seattle, WA (oral quote given on August 27, 1997)

- Copper and Brass Sales; Portland, OR (oral quote given on August 27, 1997)

- Olin Brass; Cupertino, CA (see Appendix A)

These suppliers were local offices of eastern United States fabricators. Pricing estimates for the $\mathrm{C} 10200$ and C12200 coppers are compared below in Table 8. None of these suppliers were able to quote prices for the C10800 copper as it is a special-order alloy that is not readily available (and thus would be much more expensive than either the $\mathrm{C} 10200$ or $\mathrm{C} 12200$ coppers). The $\mathrm{C} 12200$ copper is about $7 \%$ less in price than the $\mathrm{C} 10200$ copper. Fabrication costs for the $\mathrm{C} 10200$ and $\mathrm{C} 12200$ coppers would be similar.

Table 8: Cost Quotes for ASTM B-152 Coppers

\begin{tabular}{|c|c|c|c|}
\hline Supplier & Alloy & Plate/Sheet Size & Price \\
\hline \multirow[t]{2}{*}{ Alaskan Copper \& Brass* } & $\mathrm{C} 10200$ & $\begin{array}{c}0.64 \times 91 \times 305 \mathrm{~cm} \\
(0.25 \times 36 \times 120 \mathrm{in} .)\end{array}$ & $\begin{array}{l}\$ 6.62 / \mathrm{kg} \\
(\$ 3.01 / \mathrm{b})\end{array}$ \\
\hline & $\mathrm{C} 10200$ & $\begin{array}{c}0.32 \times 61 \times 244 \mathrm{~cm} \\
(0.125 \times 24 \times 96 \mathrm{in} .)\end{array}$ & $\begin{array}{c}\$ 7.68 / \mathrm{kg} \\
(\$ 3.49 / \mathrm{lb})\end{array}$ \\
\hline Copper and Brass Sales* & $\mathrm{C} 10200$ & $\begin{array}{l}0.64 \times 91 \times 244 \mathrm{~cm} \\
(0.25 \times 36 \times 96 \mathrm{in} .)\end{array}$ & $\begin{array}{l}\$ 8.21 / \mathrm{kg} \\
(\$ 3.73 / \mathrm{b})\end{array}$ \\
\hline \multirow[t]{2}{*}{ Olin Brass** } & $\mathrm{C} 10200$ & $\begin{array}{c}0.32 \times 61 \times 244 \mathrm{~cm} \\
(0.125 \times 24 \times 96 \mathrm{in} .)\end{array}$ & $\begin{array}{l}\$ 6.36 / \mathrm{kg} \\
(\$ 2.89 / \mathrm{b})\end{array}$ \\
\hline & $\mathrm{C} 12200$ & $\begin{array}{c}0.32 \times 61 \times 244 \mathrm{~cm} \\
(0.125 \times 24 \times 96 \mathrm{in} .)\end{array}$ & $\begin{array}{r}\$ 5.95 / \mathrm{kg} \\
(\$ 2.70 / \mathrm{bb}) \\
\end{array}$ \\
\hline
\end{tabular}

* Price is per plate/sheet and would decrease with a larger order.

** Price is based upon a minimum quantity of $3856 \mathrm{~kg}(8,500 \mathrm{lbs})$. 


\subsection{CONCLUSIONS}

The room temperature mechanical properties of the $\mathrm{C} 10200, \mathrm{C} 10800$, and $\mathrm{C} 12200$ coppers depend upon temper and can approximate those of 304L stainless steel at the higher-hardness tempers. C10200 and $\mathrm{Cl} 10800$ have the highest electrical and thermal conductivity while $\mathrm{C} 12200$ is about $15 \%$ lower.

Elevated temperature yield strength of $\mathrm{C} 12200$ is only slightly lower than stainless steel, but the tensile strength is only about one-third that of the stainless steel. The C10200 and C10800 coppers have 5 to $15 \%$ lower elevated temperature strength levels. The coppers are prone to stress relaxation but the addition of minute amounts of silver significantly reduce the effects. Thermal expansion coefficients for the coppers are 5-10\% larger than stainless steel; copper expansion effects should be minimal.

By virtue of composition, all three coppers are resistant to hydrogen embrittlement. The MCO environments are such that ammonia and its compounds are not present, therefore stress corrosion cracking will not occur.

Atmospheric corrosion of the coppers is negligible. Corrosion of the coppers is minimal during the short time period that the $\mathrm{MCO}$ is filled with water and during water removal.

Once water is removed from the MCO accelerated galvanic corrosion of the coppers ceases. Corrosion of the coppers by chlorine and iodine gas is not expected, however, some scaling due to oxygen is expected. The effect of liquid metal embrittlement by either cesium or tin is negligible. Radiation effects will strengthen the coppers and aid in the divider stability during hot conditioning.

Cost quotes showed $\mathrm{C} 12200$ to be about $7 \%$ less than $\mathrm{C} 10200$. C10800 is not readily available and would be more expensive as it is a special order alloy. Fabrication costs would be similar for both $\mathrm{C} 10200$ and $\mathrm{C} 12200$.

Based upon better elevated temperature strength properties and lower material cost, at the sacrifice of some conductivity, the use of $\mathrm{C} 12200$ copper is recommended over the $\mathrm{C} 10200$ and $\mathrm{C} 10800$ coppers as the Mark IA and Mark IV scrap basket divider subassembly construction material. 


\subsection{REFERENCES}

ASM, 1990, Binary Alloy Phase Diagrams, Second Edition, T. B. Massalski Editor-in-Chief, American Society for Metals, Metals Park, Ohio.

ASME, 1995, Boiler \& Pressure Vessel Code, American Society of Mechanical Engineers, New York, New York.

ASTM, 1997, "Standard Specification for Copper Sheet, Strip, Plate, and Rolled Bar" in Annual Book of ASTM Standards, Specification B-152-97, American Society for Testing and Materials, Philadelphia, Pennsylvania.

Beal, R. E. and R.E. Cook, 1993, "Brazing of Copper, Copper Alloys, and Precious Metals" in ASM Handbook, Volume 6: Welding, Brazing, and Soldering, Tenth Edition, American Society for Metals, Metals Park, Ohio, pg. 931-936.

Chawla, S. L. and R. K. Gupta, 1993, Materials Selection for Corrosion Control, American Society for Metals, Materials Park, Ohio, pg 195-211.

Craig, B., 1987, "Hydrogen Damage" in Metals Handbook, Volume 13: Corrosion, Ninth Edition, American Society for Metals, Metals Park, Ohio, pg. 163-171.

DESH, 1997A, K-Basin SNF Scrap Basket Mark 1A, H-2-828065, Rev. 1, Duke Engineering and Services Hanford, Richland, Washington.

DESH, 1997B, MCO Mark IV SNF Scrap Basket, H-2-828075, Rev. 1, Duke Engineering and Services Hanford, Richland, Washington.

Garvin, L. J., 1997, Multi-Canister Overpack Topical Report, HNF-SD-SNF-SARR-005, Fluor Daniel Hanford, Richland, Washington.

Gilbert, P. T., 1994, "Copper and Copper Alloys" in Corrosion Volume 1: Metal/Environment Reactions, Third Edition, L. L. Shrier Editor, Butterworth Heinemann, Boston, MA, pg. 4:38-4:75.

Goldmann, L. H., 1997, Performance Specification for the Spent Nuclear Fuel Multi-Canister Overpack, WHC-S-0426, Revision 3, Westinghouse Hanford Company, Richland, Washington.

Graves, C. E., 1997, Evaluation of Carbon Steel for MCO Mark IV Fuel Basket Construction, HNF-SD-SNF-ER-017, Revision 0, Duke Engineering \& Services Hanford, Richland, Washington.

Liening, E. L., 1987, "Corrosion by Chlorine" in Metals Handbook, Volume 13: Corrosion, Ninth Edition, American Society for Metals, Metals Park, Ohio, pg. 1170-1174.

Lyman, W. S., 1980, "Copper and Copper Alloys" in Encyclopedia of Chemical Processing and Design, Volume 11, J. J. McKetta Executive Editor, Marcel Dekker, inc, New York, New York, pg. 422-450.

Nicholas, M. G., 1984, "A Survey of Literature on Liquid Metal Embrittlement of Metals and Alloys" in Embrittlement by Liquid and Solid Metals, M. H. Kamdar Editor, The Metallurgical Society, Warrendale, PA, pg. 27-50. 
O'Neill, C. T., 1996A, Performance Specification for the K-Basin Spent Nuclear Fuel Hot Conditioning System Equipment, WHC-S-0460, Revision 1, Westinghouse Hanford Company, Richland, Washington.

O'Neill, C. T., 1996B, Performance Specification for the K-Basin Spent Nuclear Fuel Vacuum Drying Module, WHC-S-0435, Revision 0, Westinghouse Hanford Company, Richland, Washington.

Polan, N. W., 1987, "Corrosion of Copper and Copper Alloys" in Metals Handbook, Volume 13: Corrosion, Ninth Edition, American Society for Metals, Metals Park, Ohio, pg. 610-640.

Ricksecker, R. E., 1979, "Wrought Copper and Wrought Copper Alloys" in Kirk-Othmer Encyclopedia of Chemical Technology, Third Edition, Volume 7, M. Grayson Executive Editor, John Wiley \& Sons, New York, New York, pg 1-68.

Robinson, P., 1990, "Properties of Wrought Coppers and Copper Alloys" in ASM Handbook, Volume 2: Properties and Selection: Non-Ferrous Alloys and Special-Purpose Materials, Tenth Edition, American Society for Metals, Metals Park, Ohio, pg. 265-270.

Thurgood, M. J., 1997, Bounding Temperatures and Gas Generation Rates During CSB Staging, HNF-SD-SNF-CN-005, Revision 0, Fluor Daniel Hanford, Richland, Washington.

Tyler, D. E., 1990, "Wrought Copper and Copper Alloy Products" in ASM Handbook, Volume 2: Properties and Selection: Non-Ferrous Alloys and Special-Purpose Materials, Tenth Edition, American Society for Metals, Metals Park, Ohio, pg. 241-264.

Upthegrove, C. and H. L. Burghoff, 1956, Elevated Temperature Properties of Coppers and Copper-Base Alloys, ASTM STP \#181, American Society For Testing Materials, Philadelphia, PA, pg. 17, Data sheet $\# 7$ and pg 31, Data sheet \#4.

WHC, 1996, Fabrication Specification for the Spent Nuclear Fuel Project Multi-Canister Overpack, WHC-S-0453; Rev. 0, Westinghouse Hanford Company, Richland, Washington. 
HNF-SD-SNF-ER-019

Revision 0

\section{APPENDIX A - COST QUOTE}




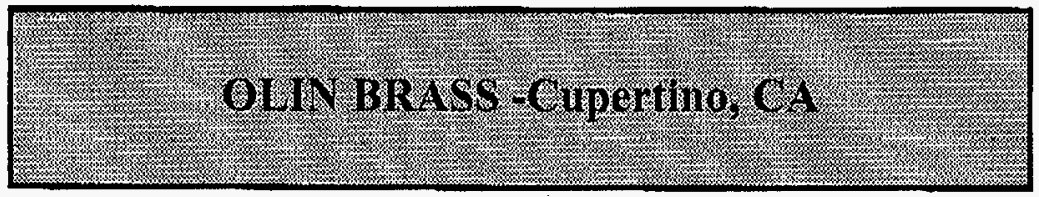

To:

Carolyn Graves

Fluor Daniel Northwest

From:

Donna

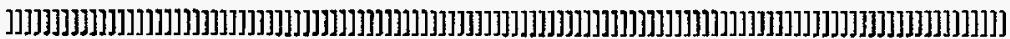
20370 Town Center Lane

Suite B-235

Cupertino, CA 95014

(408) $25 \%-5820$

(408)255-9690 fax

Date:

$9 / 05 / 97$

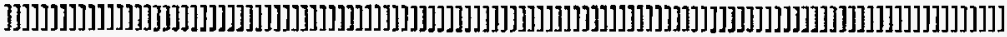

Copper Base: \$1.13

Subject: Quote

Ship: $\quad$ 10-12 weeks ARO

Freight: Prepaid

Release

$\underline{\text { Itcm }}$

Quantity

Description

Price/Lb.

1.

$8,500 \mathrm{lbs}$.

$.125 \pm .0025^{\prime \prime} \times 24.00 " \times$ CTL of $96.00 "$

$\$ 2.8863 / 1 \mathrm{~b}$

(Mininum) Soft Temper, Alloy $\mathrm{C} 102$

ASTM-B152

2.

8,500lbs.
(Minimum)

$.125 \pm .0025^{\prime \prime} \times 24.00 " \times$ CTL of 96.00 "

$\$ 2.6963 / 1 \mathrm{~b}$

(Minimum) Soft Temper, Alloy C122

ASTM-B152

<OLIN STANDARD TERMS AND CONDITYONS OF SALE APPLY>

Additional Remarks:

*Price in effect date of slip shall apply

*F.O.B. East Alton, IL

*Rreight prepaid on $8 \mathrm{M} \#$ and abovs

"No quote on the 25 " material - too heavy

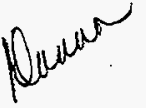

Sheet - Strip - Rod - Wire - Pipe - Tube

OLIN BRASS CORPORATION 
DISTRIBUTION SHEET

\begin{tabular}{|c|c|c|c|c|c|}
\hline \multirow{2}{*}{$\begin{array}{l}\text { To } \\
\text { Distribution }\end{array}$} & \multirow{2}{*}{\multicolumn{3}{|c|}{$\begin{array}{l}\text { From } \\
\text { Mechanisms Engineering, } \\
\text { Fluor Daniel Northwest } \\
\end{array}$}} & \multirow{2}{*}{\multicolumn{2}{|c|}{$\begin{array}{l}\text { Page } 1 \text { of } 1 \\
\text { Date September } 25,1997\end{array}$}} \\
\hline & & & & & \\
\hline \multirow{2}{*}{\multicolumn{4}{|c|}{$\begin{array}{l}\text { Project Title/Work Order } \\
\text { "Evaluation of Copper for Divider Subassembly in MCO Mark 1A and } \\
\text { Mark IV Scrap Fuel Baskets" HNF-SD-SNF-ER-019, Revision 0 }\end{array}$}} & \multirow{2}{*}{\multicolumn{2}{|c|}{$\frac{\text { EDT No. } 604540}{\text { ECN No. N/A }}$}} \\
\hline & & & & & \\
\hline Name & MSIN & $\begin{array}{c}\text { Text } \\
\text { With All } \\
\text { Attach. }\end{array}$ & $\begin{array}{l}\text { Text } \\
\text { Only }\end{array}$ & $\begin{array}{c}\text { Attach./ } \\
\text { Appendix } \\
\text { Only } \\
\end{array}$ & $\begin{array}{c}\text { EDT/ECN } \\
\text { Only }\end{array}$ \\
\hline Central Files (Org. +2 ) & A3-88 & $\mathrm{x}$ & & & \\
\hline WC Alaconis & R3-85 & $\mathrm{x}$ & & & \\
\hline GD Bazinet & B4-55 & $\mathrm{x}$ & & & \\
\hline $\mathrm{KH}$ Bergsman & R3-48 & $\mathrm{X}$ & & & \\
\hline DM Chenault & R3-86 & $\mathrm{X}$ & & & \\
\hline RG Cowan & R3-86 & $\mathrm{X}$ & & & \\
\hline \multirow{2}{*}{$\begin{array}{l}\text { DR Duncan } \\
\text { JR Frederickson }\end{array}$} & R3-86. & $\mathrm{X}$ & & & \\
\hline & R3-86 & $\mathrm{X}$ & & & \\
\hline $\begin{array}{l}\text { JR Frederickson } \\
\text { LH Goldmann }\end{array}$ & R3-86 & $\mathrm{x}$ & & & \\
\hline CE Graves (2) & $\mathrm{H} 5-70$ & $\mathrm{X}$ & & & \\
\hline CR Hoover & H1-15 & $\mathrm{x}$ & & & \\
\hline FF Huang & H5-70 & $\mathrm{X}$ & & & \\
\hline JJ Lrwin & $\mathrm{H} 0-34$ & $\mathrm{x}$ & & & \\
\hline $\begin{array}{l}\text { AT Kee } \\
\text { M: Kummerer }\end{array}$ & R3-86 & $\mathrm{X}$ & & & \\
\hline M: Kummerer & A3-34 & $\mathrm{x}$ & & & \\
\hline \multirow{2}{*}{$\begin{array}{l}\text { BD Lorenz } \\
\text { TD Merkling }\end{array}$} & R3-15 & $\mathrm{x}$ & & & \\
\hline & $\mathrm{X3-79}$ & $\mathrm{x}$ & & & \\
\hline $\begin{array}{l}\text { TD Merkling } \\
\text { CR Miska }\end{array}$ & $\mathrm{R} 3-86$ & $\mathrm{x}$ & & & \\
\hline RW Rasmussen & R3-86 & $\mathrm{x}$ & & & \\
\hline $\begin{array}{l}\text { ES Ruff } \\
\text { RE Russell }\end{array}$ & H5-70 & $\mathrm{x}$ & & & \\
\hline RE Russell & $\mathrm{H} 5-70$ & $X$ & & & \\
\hline $\begin{array}{l}\text { EJ Shen } \\
\text { DA Smith }\end{array}$ & R3-86 & $\mathrm{X}$ & & & \\
\hline \multirow{2}{*}{$\begin{array}{l}\text { DA Smith } \\
\text { KE Smith }\end{array}$} & R3-15 & $\mathrm{x}$ & & & \\
\hline & R3-86 & $\mathrm{X}$ & & & \\
\hline CE Swenson & S8-07 & $x$ & & & \\
\hline $\begin{array}{l}\text { JA Swenson } \\
\text { CA. Thompson }\end{array}$ & $\mathrm{R} 3-11$ & $\mathrm{X}$ & & & \\
\hline & $\mathrm{R} 3-85$ & $\mathrm{x}$ & & & \\
\hline
\end{tabular}

